\title{
The Restrictive Type, Infectious Complications, a Long Duration of Illness Might Predict Nadir Hematological Values Among Individuals With Anorexia Nervosa During the Refeeding Period: A Retrospective Study
}

Michitaka Funayama ( $\nabla$ mctkfnym@gmail.com )

Ashikaga Red Cross Hospital https://orcid.org/0000-0002-4473-9179

Akihiro Koreki

Keio University School of Medicine Graduate School of Medicine: Keio Gijuku Daigaku Igakubu

Daigakuin Igaku Kenkyuka

Yu Mimura

Keio University School of Medicine Graduate School of Medicine: Keio Gijuku Daigaku Igakubu

Daigakuin Igaku Kenkyuka

Taketo Takata

Ashikaga Red Cross Hospital: Ashikaga Sekijuji Byoin

Satoyuki Ogino

Kyorin University: Kyorin Daigaku

\section{Shin Kurose}

Keio University School of Medicine Graduate School of Medicine: Keio Gijuku Daigaku Igakubu

Daigakuin Igaku Kenkyuka

Yusuke Shimizu

Kyorin University: Kyorin Daigaku

\section{Shun Kudo}

Keio University School of Medicine Graduate School of Medicine: Keio Gijuku Daigaku Igakubu Daigakuin Igaku Kenkyuka

Research article

Keywords: anorexia nervosa, restrictive type, anemia, leukopenia, thrombocytopenia, pancytopenia, infection, duration of illness

Posted Date: November 19th, 2021

DOI: https://doi.org/10.21203/rs.3.rs-1078017/v1 
License: (c) (i) This work is licensed under a Creative Commons Attribution 4.0 International License. Read Full License 


\section{Abstract}

\section{Background}

Although hematological abnormalities in patients with anorexia nervosa have been documented, the mechanisms involved have not been fully clarified, especially during the refeeding period, when hematological values further decrease after admission prior to improving. Here we address potential mechanisms underlying the hematological abnormalities of anorexic inpatients during the refeeding period.

\section{Methods}

We recruited patients from 101 admissions corresponding to 55 individual patients with anorexia nervosa with severe malnutrition (body mass index, $13.4 \pm 3.4$ ) from the neuropsychiatry unit in Ashikaga Red Cross Hospital during the period from October 1999 to March 2018. We analyzed three hematological cell measures (hemoglobin, white blood cells, platelets) to determine their levels at admission and their lowest levels during the refeeding period and calculated the rate of decrease in those values from admission to the nadir levels. We analyzed each measure using a general mixed model with explanatory variables, including data upon admission and a treatment-related indicator.

Results

The initial hemoglobin value of $12.1 \pm 2.7 \mathrm{~g} / \mathrm{dl}$ decreased by $22.3 \%$ to $9.4 \pm 2.5 \mathrm{~g} / \mathrm{dl}$; the initial white cell count was $5387 \pm 3474 / \mu \mathrm{l}$, which decreased by $33.6 \%$ to $3576 \pm 1440 / \mu \mathrm{l}$; the initial platelet count of 22.6 $\pm 10.1 \times 10^{4} / \mu \mathrm{l}$ decreased by $24.3 \%$ to $17.1 \pm 8.0 \times 10^{4} / \mu \mathrm{l}$. All nadir levels were observed during the refeeding period from the fifth to tenth day of hospitalization. The anorexia nervosa restrictive type was associated with a lower nadir level of hemoglobin and white blood cell count. Infectious complications were related to a lower nadir level of hemoglobin and platelet count. A longer duration of illness was associated with a lower nadir white blood cell count.

\section{Conclusions}

Nadir hematological cell measures of inpatients with anorexia nervosa during the refeeding period might be predicted by the restrictive type, infectious complications, and a long duration of illness. These factors might be used as indicators to guide clinical approaches for controlling hematological deficiencies during the refeeding period.

\section{Plain English Summary}

Deficiencies in components of the blood, such as a low red blood cell count, low white blood cell count, and low platelet numbers, are observed frequently in patients with anorexia nervosa, particularly those with severe malnutrition, and these deficiencies often deteriorate further after hospitalization during the initial period when patients are reintroduced to food. Why this deterioration occurs even under medical 
care is not well understood. Here we analyzed the patient factors associated with these blood cell-related (i.e., hematological) abnormalities. Patients with the restrictive type of anorexia nervosa, a longer duration of illness, and infectious complications were more likely to have the lowest levels of hematological values during the refeeding period.

\section{Background}

Hematological deficiencies, i.e., anemia, leukopenia, and thrombocytopenia, are often found in patients with anorexia nervosa. Their prevalence has been reported to range from 21 to $39 \%$ for anemia, 29 to $36 \%$ for leukopenia, and 5 to $11 \%$ for thrombocytopenia [1]. Recent reports of anorexic patients with severe malnutrition have further provided a higher frequency of hematological abnormalities: 47 to $83 \%$ for anemia, 53 to $79 \%$ for leukopenia, and 20 to $25 \%$ for thrombocytopenia [2-4]. Pancytopenia, a decline in all three hematological measures, is also occasionally found in anorexic patients, and its frequency was reported to be $23 \%$ among anorexic patients with severe malnutrition [2]. Indeed, anemia is considered one of the predictors of mortality for anorexic patients; the 5-year mortality rate for anorexic patients with severe undernutrition is $11.5 \%$, and their mortality risk is 15 times higher than that in the general population [5]. Regarding life expectancy, Harbottle et al. estimated that a woman who has had anorexia nervosa since 15 years of age is likely to live 25 years less than predicted for the normal population [6].

Hematological deficiencies of patients with anorexia nervosa result from bone marrow hypoplasia with gelatinous marrow transformation or serous atrophy of bone marrow [1, 2], which typically resolve with nutritional rehabilitation [7]. Accordingly, these hematological deficiencies have been associated with malnutrition and its related circumstances in these patients, i.e., a low body mass index $[2,8,9]$, the restrictive type of anorexia nervosa $[3,5]$, and the duration of illness [8]. These previous studies, however, did not control for potential confounding factors.

Most of the previous studies concerning hematological abnormalities in patients with anorexia nervosa used hematological values at outpatient clinics or upon admission. The lowest hematological values, however, are observed during the refeeding period, 1 week after admission $[2,10]$. In fact, even these patients show a V-shaped recovery, their hematological values at the time of discharge are still lower that those upon admission [2]. This is partly because patients with anorexia nervosa are frequently admitted with extracellular fluid volume depletion due to malnutrition and its associated blood plasma decrease or hemoconcentration $[2,8]$, in which hemoglobin and platelet cell counts per unit of blood volume are elevated [11-13], which makes it difficult to evaluate the hematological deficiencies of these patients upon admission. Another hypothesized mechanism behind nadir hematological values during the refeeding period is a "comet-tail" effect on organ systems after prolonged prior caloric restriction [2], in which it takes about a week of refeeding for the bone marrow to begin responding effectively and produce a substantial number of blood cells. Furthermore, hematological values might be influenced by infectious complications, in which anemia, leukopenia/leukocytosis, and thrombocytopenia/thrombocytosis were frequently observed [14-19]. Infectious diseases are one of the most common complications of anorexia nervosa. According to Guinhut et al. [4], 24.3\% of anorexic 
patients with extremely severe malnutrition developed one or several infectious complications during their hospital stay. This potential influence of infectious diseases on hematological values has not been addressed in previous studies.

Thus, it is crucial for clinicians to precisely predict the nadir hematological levels and the rate of decrease in these levels during the refeeding period because anorexic patients typically experience nadir values after being refed, suggesting that there might be life-threatening hematological conditions not only at admission but also during the refeeding period. However, the factors behind the nadir hematological levels have not been examined. Thus, in this study, we carried out a retrospective investigation of the mechanisms underlying the hematological deficiencies in anorexic patients not only at admission but also during the refeeding period, and we evaluated comprehensive variables-including indicators associated with malnutrition, volume depletion, infections complications, and a treatment-associated factor-that potentially influence these hematological values.

\section{Methods}

\section{Participants}

Ethical aspects of this study were reviewed and approved by the Human Research Ethics Committee at Ashikaga Red Cross Hospital. This study was performed after obtaining informed consent from all participants upon admission. For patients below the age of 18 years, informed parental consent was also obtained. Diagnosis was based on criteria in the ICD-10, and each patient was diagnosed by two of the three psychiatrists, each of whom is a board-certified specialist for psychiatry and had $>10$ years of experience in psychiatry at the time of the study. Participants were recruited from the neuropsychiatric unit in Ashikaga Red Cross Hospital during the period from October 1999 to March 2018, during which there were 101 admissions with anorexia nervosa (F50.0) from 55 individual patients that were managed in our unit. These were categorized into the restrictive type (F50.01, anorexia nervosa, restricting type) and the binge-purge type (F50.02, anorexia nervosa, binge eating/purging type) by two of the three psychiatrists. Among a total of 55 individual patients, all of whom were Japanese, 19 had two or more consecutive admissions, which added up to a total of 101 admissions. These 101 admissions were used for hemoglobin values at admission (Table 1). Regarding the lowest levels and the rate of decrease in these three cell measures, we gathered data from admissions for which the lowest level of each blood cell measure was confirmed, that is, individual patients who showed a V-shaped recovery during the refeeding period. Conversely, we excluded the admissions in which each blood cell measure of the individual patients did not a V-shaped recovery. Thus, of 101 admissions from 55 patients, 78 admissions from 45 patients were used for the nadir hemoglobin value, 76 admissions from 43 patients for the nadir white blood cell count, and 75 admissions from 43 patients for the nadir platelet count (Table 1).

\section{Collection of patient information}

Electronic medical records of eligible participants were retrospectively reviewed. As outcome indicators, the following three measures were used: the hemoglobin value, white blood cell count, and platelet count. 
We determined these values at admission, determined their nadir hematological values during the refeeding period, and determined the rate of decrease (the extent of decrease divided by the value at admission). To differentiate hemoconcentration from polycythemia, their hematocrit values were also counted. Explanatory variables included demographics (duration of illness, sex, body mass index, presence of chronic kidney diseases, anorexia nervosa subtype, i.e., restrictive or binge-purge), laboratory data at admission (blood urea nitrogen/creatinine [BUN/Cr] ratio and aspartate aminotransferase [ALT]), presence of infectious diseases, and an indicator involving treatment, i.e., the amount of caloric intake. Body mass index was calculated as the weight of the individual (in kilograms) divided by the square of the height of the individual (in meters). The BUN/Cr ratio was used to indicate the degree of volume depletion or hemoconcentration, although other conditions, e.g., protein-energy malnutrition and the catabolic state, might contribute to a higher BUN/Cr ratio in patients with anorexia nervosa [20]. The presence of chronic kidney disease (glomerular filtration rate(GFR) $₫ 60 \mathrm{~mL} / \mathrm{min} / 1.73 \mathrm{~m}^{2}$ for three months or longer) was counted as an explanatory variable only for hemoglobin analysis because anemia is a common complication of chronic kidney disease [21]. Values of ALT, an indicator of liver function, were also evaluated as an explanatory variable only for platelet count analysis, low levels of which are often resulted from liver dysfunction $[22,23]$. Because elevation of transaminases in patients with anorexia nervosa is common not only at admission but also during the refeeding period even with a worsening [24-26], ALT values at admission were used for platelet values at admission while the maximum ALT values during the hospital stay were used for the nadir platelet cell counts and the rate of the decrease in the values. As the ALT values were not normally distributed, they were used for this analysis only after logarithmic transformation [27]. Regarding the presence of infectious diseases, when a patient already contracted an infectious disease at the time of admission, the presence of infectious complications at admission was used as an explanatory variable for hematological values at admission. For hematological values during the refeeding period (the nadir hematological values and the rate of decrease in the values), the presence of infectious diseases during the hospital stay (both at admission and during the refeeding period) was counted. As a treatment-related indicator, the caloric intake was measured because it frequently affects laboratory data during the refeeding period $[20,28,29]$. Caloric intake (in kilocalories) refers to the average total caloric intake from day 1 through day 7 [20, 28, 29], including both oral intake and intravenous infusion therapy. If the patient ate only half the provided 1200$\mathrm{kcal}$ meal, the actual amount of total caloric intake was recorded as $600 \mathrm{kcal}$. To accurately investigate the effect of energy intake on an individual patient depending on his or her weight, we used the total caloric intake per body weight at admission for this analysis [20,29]; this measure is widely used for diet therapy for diabetes mellitus [30].

A laboratory panel was carried out upon admission. Regarding tests used for the measurement of the nadir level and the rate of decrease in the three blood cell measures as well as the measurement of ALT values during the refeeding period, each blood test from the second examination onward was conducted at 7:30 in the morning before breakfast. To precisely identify the nadir levels, the patients frequently underwent serial laboratory tests: 52 admissions (64.2\%) were tested on the second hospital day, 43 $(53.1 \%)$ on the third and fourth hospital days, 35 (43.2\%) on the fifth hospital day, 32 (39.5\%) on the sixth 
hospital day, 27 (33.3\%) on the seventh hospital day, 31 (38.2\%) on the eighth hospital day, $17(21.0 \%)$ on the ninth hospital day, and $14(17.3 \%)$ on the tenth hospital day. The second laboratory panel was carried out for 66 admissions (81.5\%) by the fourth hospital day and in 75 admissions (92.6\%) by the seventh hospital day. These patients basically continued to have blood tests until their blood cell counts went up or showed a V-shaped recovery. The measurement of vitamin B12, folate, and reticulocytes was not routinely conducted, but were performed as needed.

\section{Protocol for refeeding}

The initial caloric prescription for each patient was determined by the degree of malnutrition, caloric intake preceding admission, and the weight of each patient. Although caloric intake was administered mainly through oral food, intravenous infusion therapy was sometimes used and, less frequently, nasogastric feeding was also carried out. Normally, the total initial caloric prescription consisted of $\sim 600-1400 \mathrm{kcal} /$ day and was usually increased by $200 \mathrm{kcal}$ every day.

\section{Statistical analysis}

Associations between the three hematological cell measures and patient factors were investigated using values at admission, nadir values during the refeeding period, and the ratio of the decrease within each patient for these values. The general mixed model was used to deal with repetitive admissions, in which individuals were used as random intercepts and other variables as explanatory variables, i.e., demographics (duration of illness, sex, body mass index, and anorexia nervosa subtype), laboratory data (BUN/Cr ratio and ALT), presence of infectious diseases, presence of chronic kidney disease for hemoglobin analysis, and the treatment-related indicator (caloric intake). No single numerical variable had a correlation of $>0.35$ with other variables, indicating that all numeric variables were relatively independent, such that all variables were included in the general mixed model. For analysis of the hematological value at admission, the treatment-related indicator was excluded from the explanatory variables.

Given the frequent occurrence of pancytopenia, correlations among the three cell measures were also investigated by using multilevel correlation analyses, which were conducted for the values at admission $(N=101)$, the nadir values during the refeeding period $(n=73)$, and the rate of the decrease in the values $(n=73)$. The latter two cohorts included 73 admissions with confirmed nadir levels for all three hematological cell measures. For all statistical tests, two-tailed $p$-values of $<0.05$ were considered significant. All statistical analyses were conducted with $\mathrm{R}$ (4.1.1).

\section{Results}

Table 1 shows demographic factors and data both at admission and during the refeeding period for admissions with anorexia nervosa. The first column shows data for 101 admissions from 55 individual patients that were used for the hematological values at admission. The other three columns display data for admissions used for the nadir value and the rate of the decrease of each hematological value: hemoglobin value ( $n=78$ from 45 patients), white blood cell count ( $n=76$ from 43 patients), and platelet 
count ( $n=75$ from 43 patients). The average body mass index for all admissions was $13.4 \pm 3.4$, suggesting that this cohort consisted of anorexia nervosa patients with severe malnutrition because a body mass index of $<16$ is considered severe malnutrition among patients with anorexia nervosa [31].

The initial hemoglobin value of $12.1 \pm 2.7 \mathrm{~g} / \mathrm{dl}$ decreased by $22.3 \%$ to $9.4 \pm 2.5 \mathrm{~g} / \mathrm{dl}$, which was observed at $10.1 \pm 9.2$ days after admission; the white cell count at admission was $5387 \pm 3474 / \mu \mathrm{l}$, which decreased by $33.6 \%$ to $3576 \pm 1440 / \mu \mathrm{l}$ at $9.8 \pm 10.0$ days after admission; the initial platelet count of 22.6 $\pm 10.1 \times 10^{4} / \mu \mathrm{l}$ decreased by $24.3 \%$ to $17.1 \pm 8.0 \times 10^{4} / \mu \mathrm{l}$, which was observed $5.5 \pm 4.9$ days after admission. The mean corpuscular volume was $91.3 \pm 9.4 \mathrm{fl}$. The number of admissions with mean corpuscular volume $<80 \mathrm{fl}$ (microcytic anemia) was 7 (6.9\%), whereas the number of admissions with mean corpuscular volume $>100 \mathrm{fl}$ (macrocytic anemia) was 16 (15.8\%), suggesting that most admissions $(n=78,77.2 \%)$ involved normocytic normochromic anemia. Among the 16 admissions with macrocytic anemia, 6 admissions from 5 individual patients were investigated for levels of vitamin B12 and folate, and none had deficiencies for those levels. Of 22 admissions with macrocytic anemia at admission or during the refeeding period, 9 individual patients received assessment of the ratio of reticulocytes, the average of which was high at $4.9 \%$ (the normal value is $0.8-2.2 \%$ ), whereas all their hemoglobin values were $<10.1 \mathrm{~g} / \mathrm{dl}$. Among 73 admissions with confirmed nadir levels for all three hematological cell measures, pancytopenia (hemoglobin $<11 \mathrm{~g} / \mathrm{dl}$, white blood cells $<4000 / \mu \mathrm{l}$, and platelets $<10 \times 10^{4} / \mu \mathrm{l}$ [32]) was observed in 12 admissions (16.4\%). Anemia (hemoglobin $<11 \mathrm{~g} / \mathrm{dl}$ ) was highly prevalent, with $59.4 \%$ of admissions having anemia at some point during their hospitalization (60 of 101 admissions). Leukopenia (white blood cells $<4000 / \mu \mathrm{l}$ ) occurred in $49.5 \%$ of admissions (50 of 101 admissions). Thrombocytopenia (platelets $<10 \times 104 / \mu \mathrm{l}$ ) was seen in $16.8 \%$ of patients (17 of 101 admissions). Although the hematocrit levels at admission in 7 patients were $>45 \%$, their hematocrit levels during the refeeding period decreased to $<39$, suggesting that no patients experienced polycythemia, which is defined as having a hematocrit level of $>45 \%$ [33]. Red blood cell transfusion was used to treat 12 admissions from 11 individual patients whose average hemoglobin value was $5.1 \mathrm{~g} / \mathrm{dl}$ (range: 1.7-7.4 $\mathrm{g} / \mathrm{dl}$ ). Platelet transfusion was undertaken for two admissions from two individual patients whose nadir platelet cell counts were 0.4 and $1.7 \times 10^{4} / \mu$, respectively.

Infectious diseases were found in 10 admissions (9.9\%) from 9 individual patients (4 admissions from 4 individual patients at the time of admission and 6 admissions from 6 individual patients during the refeeding period, with one patient contracting infectious diseases at different times). Of those 10 admissions, 5 had pneumonia, 4 had urinary tract infections, 2 had central line associated bloodstream infections, 1 had cholangitis, and 1 had infection with unknown origin, with 3 had two types of infectious diseases at the same time. Disseminated intravascular coagulation [34] was observed in 4 admissions, in which all their platelet counts decreased to $<5.0 \times 10^{4}$.

Table 2 summarizes the results of analyses with a general mixed model. The detailed results for each hematological value are displayed in Table 3 for hemoglobin, in Table 4 for white blood cells, and in Table 5 for platelets. The restrictive type of anorexia nervosa was associated with a lower nadir white blood cell count ( $p=0.001$; Table 4B) as well as with a lower nadir hemoglobin level ( $p=0.017$; Table 3B). A lower 
nadir white blood cell count was also associated with a longer duration of illness ( $p=0.019$; Table 4B). A lower body mass index was associated with a lower white blood cell count at admission $(p=0.004$; Table $4 A)$. The presence of infectious complications was associated with a lower nadir hemoglobin level $(p<$ 0.001 ; Table 3B) and a lower nadir platelet count $(p<0.001$; Table 5B) as well as a greater rate of decrease in all three cell measures $(p<0.001$ for hemoglobin [Table $3 C$ ], $p=0.036$ for white blood cell [Table 4C], and $p<0.001$ for platelet [Table 5C]). A greater rate of decrease in the platelet count $(p=0.022$; Table 5C) was also associated with a higher BUN/Cr ratio. The presence of chronic kidney disease was associated with a lower nadir hemoglobin level ( $p=0.009$; Table 3B). Female sex was associated with a greater rate of decrease in the white blood cell count $(p=0.043$; Table 4C). An elevated ALT had a tendency to lower the platelet count at admission $(p=0.068$; Table $5 \mathrm{~A})$ and the nadir platelet count $(p=$ 0.065 ; Table 5B).

All correlations among the three hematological cell measures were statistically significant, except for the correlation between hemoglobin and white blood cell levels at admission (Table 6). 
Table 1

Demographic factors and data at admission and during the refeeding period

\begin{tabular}{|c|c|c|c|c|c|}
\hline Characteristic & & $\begin{array}{l}\text { Admissions for } \\
\text { hematological } \\
\text { level at } \\
\text { admission ( } \mathrm{N}= \\
101 \text { from } 55 \\
\text { patients) }\end{array}$ & $\begin{array}{l}\text { Admissions } \\
\text { for nadir } \\
\text { hemoglobin } \\
\text { value (n = } 78 \\
\text { from } 45 \\
\text { patients) }\end{array}$ & $\begin{array}{l}\text { Admissions } \\
\text { for nadir white } \\
\text { blood cell } \\
\text { count ( } n=76 \\
\text { from } 43 \\
\text { patients) }\end{array}$ & $\begin{array}{l}\text { Admissions } \\
\text { for nadir } \\
\text { platelet } \\
\text { count (n = } \\
75 \text { from } 43 \\
\text { patients) }\end{array}$ \\
\hline \multirow[t]{4}{*}{ Demographics } & Age (years) & $33.4 \pm 11.2$ & $35.9 \pm 10.4$ & $35.4 \pm 10.4$ & $36.1 \pm 10.6$ \\
\hline & $\begin{array}{l}\text { Sex (female } \\
\text { participants, } \\
\%)\end{array}$ & $96.0 \%$ & $97.4 \%$ & $97.4 \%$ & $97.3 \%$ \\
\hline & $\begin{array}{l}\text { Duration of } \\
\text { illness } \\
\text { (years) }\end{array}$ & $10.8 \pm 9.9$ & $12.1 \pm 9.9$ & $12.1 \pm 9.8$ & $12.8 \pm 9.9$ \\
\hline & $\begin{array}{l}\text { Restrictive } \\
\text { type (\%) }\end{array}$ & $57.4 \%$ & $64.1 \%$ & $63.2 \%$ & $62.7 \%$ \\
\hline \multirow{7}{*}{$\begin{array}{l}\text { Data at } \\
\text { admission }\end{array}$} & Weight (kg) & $33.8 \pm 9.0$ & $31.7 \pm 7.7$ & $32.3 \pm 7.4$ & $31.4 \pm 7.3$ \\
\hline & $\begin{array}{l}\text { Body mass } \\
\text { index } \\
\left(\mathrm{kg} / \mathrm{m}^{2}\right)\end{array}$ & $13.4 \pm 3.4$ & $12.5 \pm 2.8$ & $12.3 \pm 2.6$ & $12.4 \pm 2.6$ \\
\hline & $\begin{array}{l}\mathrm{BUN} / \mathrm{Cr} \\
\text { ratio }\end{array}$ & $29.1 \pm 18.2$ & $30.4 \pm 19.4$ & $30.9 \pm 19.4$ & $30.5 \pm 19.7$ \\
\hline & $\begin{array}{l}\text { Hemoglobin } \\
(\mathrm{g} / \mathrm{dl})\end{array}$ & $12.1 \pm 2.5$ & $12.1 \pm 2.7$ & NA & NA \\
\hline & $\begin{array}{l}\text { Mean } \\
\text { corpuscular } \\
\text { volume (fl) }\end{array}$ & $91.3 \pm 9.4$ & $92.1 \pm 9.9$ & NA & NA \\
\hline & $\begin{array}{l}\text { White blood } \\
\text { cells }(/ \mu l)\end{array}$ & $5621 \pm 3255$ & NA & $5387 \pm 3474$ & NA \\
\hline & $\begin{array}{l}\text { Platelets } \\
\left(\times 10^{4} / \mu \mathrm{l}\right)\end{array}$ & $24.1 \pm 10.6$ & NA & NA & $22.6 \pm 10.1$ \\
\hline \multirow[t]{2}{*}{$\begin{array}{l}\text { Caloric intake } \\
\text { and weight } \\
\text { gain }\end{array}$} & $\begin{array}{l}\text { Total caloric } \\
\text { intake } \\
\text { during the } \\
\text { first } 7 \text { days } \\
\text { (kcal/day) }\end{array}$ & NA & $1183 \pm 563$ & $1176 \pm 538$ & $1215 \pm 563$ \\
\hline & $\begin{array}{l}\text { Weight at } \\
\text { discharge } \\
\text { (kg) }\end{array}$ & $35.7 \pm 7.9$ & $34.1 \pm 6.9$ & $34.8 \pm 6.7$ & $33.9 \pm 6.7$ \\
\hline
\end{tabular}




\begin{tabular}{|c|c|c|c|c|c|}
\hline Characteristic & & $\begin{array}{l}\text { Admissions for } \\
\text { hematological } \\
\text { level at } \\
\text { admission ( } \mathrm{N}= \\
101 \text { from } 55 \\
\text { patients) }\end{array}$ & $\begin{array}{l}\text { Admissions } \\
\text { for nadir } \\
\text { hemoglobin } \\
\text { value (n = } 78 \\
\text { from } 45 \\
\text { patients) }\end{array}$ & $\begin{array}{l}\text { Admissions } \\
\text { for nadir white } \\
\text { blood cell } \\
\text { count ( } n=76 \\
\text { from } 43 \\
\text { patients) }\end{array}$ & $\begin{array}{l}\text { Admissions } \\
\text { for nadir } \\
\text { platelet } \\
\text { count ( } n= \\
75 \text { from } 43 \\
\text { patients) }\end{array}$ \\
\hline \multirow{3}{*}{$\begin{array}{l}\text { Data during } \\
\text { refeeding } \\
\text { period } \\
\text { (hospital day } \\
\text { when nadirs } \\
\text { were } \\
\text { observed) }\end{array}$} & $\begin{array}{l}\text { Nadir } \\
\text { hemoglobin } \\
\text { value }(\mathrm{g} / \mathrm{dl})\end{array}$ & NA & $\begin{array}{l}9.4 \pm 2.5 \\
(10.1 \pm 9.2)\end{array}$ & NA & NA \\
\hline & $\begin{array}{l}\text { Nadir white } \\
\text { blood cell } \\
\text { count }(/ \mu \mathrm{l})\end{array}$ & NA & NA & $\begin{array}{l}3576 \pm 1440 \\
(9.8 \pm 10.0)\end{array}$ & NA \\
\hline & $\begin{array}{l}\text { Nadir } \\
\text { platelet } \\
\text { count }\left(\cdot 10^{4} /\right. \\
\mu l)\end{array}$ & NA & NA & NA & $\begin{array}{l}17.1 \pm 8.0 \\
(5.5 \pm 4.9)\end{array}$ \\
\hline
\end{tabular}

BUN/Cr ratio, blood urea nitrogen / creatinine ratio; NA, not applicable.

Table 2

Factors associated with hematological deficiencies

\begin{tabular}{|c|c|c|c|}
\hline $\begin{array}{l}\text { Hematological } \\
\text { value }\end{array}$ & $\begin{array}{l}\text { Associated with value at } \\
\text { admission }\end{array}$ & $\begin{array}{l}\text { Associated with value at } \\
\text { nadir count }\end{array}$ & $\begin{array}{l}\text { Associated with rate of } \\
\text { decrease }\end{array}$ \\
\hline \multirow[t]{3}{*}{ Hemoglobin } & \multirow[t]{3}{*}{ N.S. } & Infection* & \multirow[t]{3}{*}{ Infection* } \\
\hline & & Chronic kidney disease* & \\
\hline & & Restrictive type ${ }^{\star \star}$ & \\
\hline \multirow{2}{*}{$\begin{array}{l}\text { White blood } \\
\text { cells }\end{array}$} & \multirow[t]{2}{*}{ Body mass index* } & Restrictive type* & Infection** \\
\hline & & Duration of illness ${ }^{\star \star}$ & Female** \\
\hline \multirow[t]{2}{*}{ Platelets } & \multirow[t]{2}{*}{ N.S. } & \multirow[t]{2}{*}{ Infection** } & Infection* \\
\hline & & & BUN/Cr ratio** \\
\hline
\end{tabular}

Table 3 Factors associated with hemoglobin value

\section{A. Hemoglobin value at admission}




\begin{tabular}{|c|c|c|c|}
\hline Item & Beta & Standard error & $P$ \\
\hline Chronic kidney disease & -1.941 & 1.333 & 0.149 \\
\hline Infection & 1.304 & 1.142 & 0.257 \\
\hline Restrictive type & -0.827 & 0.746 & 0.271 \\
\hline Duration of illness & -0.023 & 0.045 & 0.608 \\
\hline Body mass index & -0.017 & 0.102 & 0.866 \\
\hline Female & -0.242 & 1.523 & 0.875 \\
\hline BUN/Cr ratio & 0.001 & 0.016 & 0.944 \\
\hline
\end{tabular}

\begin{tabular}{|c|c|c|c|}
\hline Item & Beta & Standard error & $P$ \\
\hline Infection & -3.220 & 0.685 & $<0.001 *$ \\
\hline Chronic kidney disease & -3.559 & 1.304 & $0.009 *$ \\
\hline Restrictive type & -1.787 & 0.725 & 0.017 ** \\
\hline Energy intake & -0.013 & 0.013 & 0.319 \\
\hline Female & -1.724 & 1.786 & 0.340 \\
\hline $\mathrm{BUN} / \mathrm{Cr}$ ratio & -0.012 & 0.015 & 0.418 \\
\hline Duration of illness & 0.011 & 0.041 & 0.798 \\
\hline Body mass index & 0.014 & 0.117 & 0.900 \\
\hline \multicolumn{4}{|c|}{ Items with bold formatting are statistically significant factors. } \\
\hline \multicolumn{4}{|l|}{$* p<0.01, * * p<0.05$} \\
\hline
\end{tabular}




\begin{tabular}{|llll|}
\hline Item & Beta & Standard error & $\boldsymbol{P}$ \\
\hline Infection & 21.94 & 4.800 & $<0.001$ * \\
\hline Female & 14.36 & 9.461 & 0.134 \\
\hline Body mass index & -0.924 & 0.672 & 0.177 \\
\hline BUN/Cr ratio & 0.114 & 0.090 & 0.209 \\
\hline Restrictive type & 4.070 & 3.504 & 0.254 \\
\hline Duration of illness & -0.176 & 0.195 & 0.371 \\
\hline Chronic kidney disease & 7.218 & 8.107 & 0.377 \\
\hline Energy intake & 0.036 & 0.084 & 0.672 \\
\hline * $p<0.01$ & & & \\
\hline
\end{tabular}

Table 4 Factors associated with white blood cell count

\section{A. White blood cell count at admission}

\begin{tabular}{|lllll|}
\hline Item & Beta & Standard error & $\boldsymbol{P}$ \\
\hline Body mass index & $\mathbf{3 0 2 . 5}$ & $\mathbf{1 0 1 . 6}$ & $\mathbf{0 . 0 0 4}$ \\
\hline Infection & 2037 & 1113 & 0.071 \\
\hline BUN/Cr ratio & 22.95 & 15.74 & 0.148 \\
\hline Restrictive & -578.4 & 718.6 & 0.423 \\
\hline Female & 971.4 & 1535 & 0.530 \\
\hline Duration of illness & 5.70 & 45.70 & 0.901 \\
\hline * $p<0.01$ & & & \\
\hline
\end{tabular}

B. Nadir white blood cell count during refeeding period 


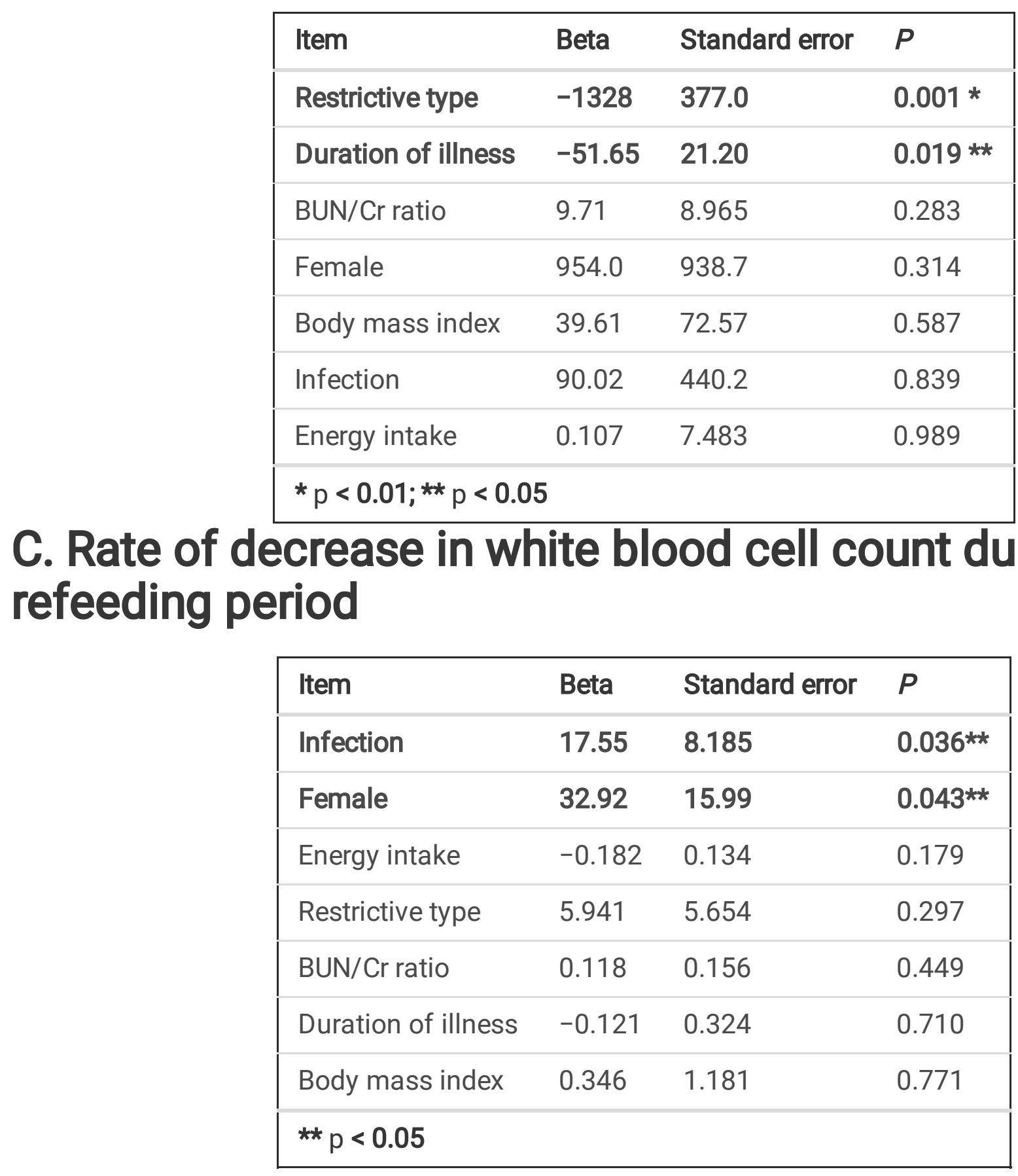

Table 5 Factors associated with platelet count

\section{A. Platelet count at admission}




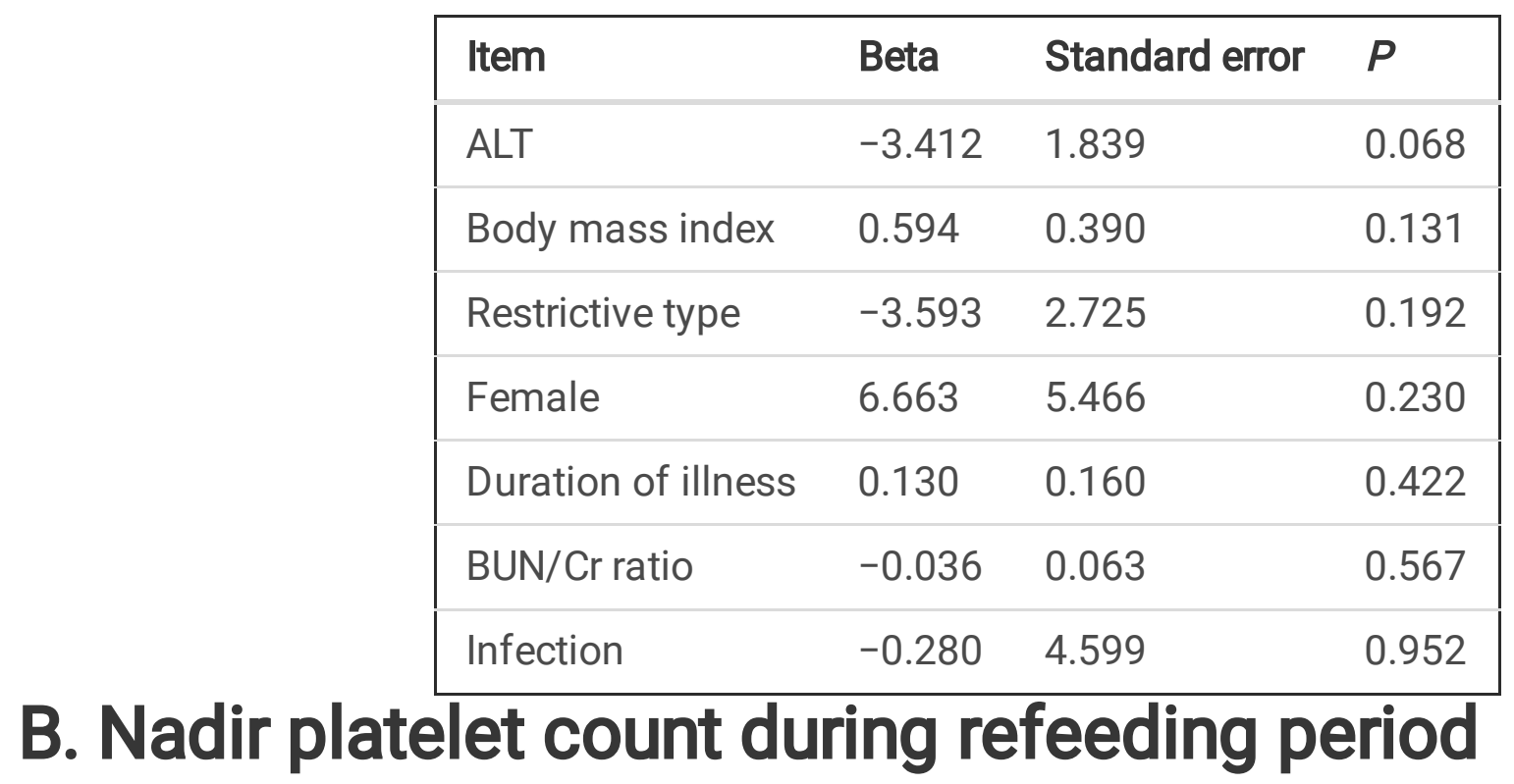

\begin{tabular}{|llll|}
\hline Item & Beta & Standard error & $\boldsymbol{P}$ \\
\hline Infection & -4.778 & $\mathbf{2 . 0 5 7}$ & $\mathbf{0 . 0 2 4}$ ** \\
\hline BUN/Cr ratio & -0.089 & 0.045 & 0.053 \\
\hline Restrictive type & -4.040 & 2.091 & 0.059 \\
\hline ALT & -2.604 & 1.384 & 0.065 \\
\hline Body mass index & 0.341 & 0.355 & 0.340 \\
\hline Female & 4.763 & 5.005 & 0.347 \\
\hline Energy intake & 0.022 & 0.037 & 0.544 \\
\hline Duration of illness & -0.044 & 0.117 & 0.709 \\
\hline ** $p<0.05$ & & & \\
\hline
\end{tabular}

\section{Rate of decrease in platelet count during refeeding period}




\begin{tabular}{|c|c|c|c|}
\hline Item & Beta & Standard error & $P$ \\
\hline Infection & 28.98 & 6.573 & $<0.001^{\star}$ \\
\hline BUN/Cr ratio & 0.316 & 0.135 & 0.022 ** \\
\hline Restrictive type & 8.383 & 5.914 & 0.164 \\
\hline ALT & -5.266 & 4.335 & 0.229 \\
\hline Duration of illness & 0.364 & 0.324 & 0.269 \\
\hline Body mass index & -0.988 & 1.080 & 0.364 \\
\hline Female & -5.665 & 13.98 & 0.687 \\
\hline Energy intake & -0.003 & 0.116 & 0.979 \\
\hline \multicolumn{4}{|c|}{$* p<0.01 ; * * p<0.05$} \\
\hline
\end{tabular}

Table 6

Multilevel correlation coefficient among the three cell measures

\begin{tabular}{|c|c|c|c|}
\hline & Item & Coefficient & $P$ \\
\hline \multirow[t]{3}{*}{ Value at admission } & Hemoglobin and white blood cells & 0.17 & 0.084 \\
\hline & Hemoglobin and platelets & 0.27 & $0.011^{\star *}$ \\
\hline & White blood cells and platelets & 0.43 & $<0.001^{*}$ \\
\hline \multirow[t]{3}{*}{ Nadir value } & Hemoglobin and white blood cells & 0.43 & $<0.001^{*}$ \\
\hline & Hemoglobin and platelets & 0.48 & $<0.001^{*}$ \\
\hline & White blood cells and platelets & 0.42 & $<0.001^{*}$ \\
\hline \multirow[t]{3}{*}{ Rate of decrease } & Hemoglobin and white blood cells & 0.39 & $0.001 *$ \\
\hline & Hemoglobin and platelets & 0.49 & $<0.001^{*}$ \\
\hline & White blood cells and platelets & 0.31 & $0.007 *$ \\
\hline
\end{tabular}

\section{Discussion}

Three new findings were derived from our present study. First, the lowest hematological values, which were decreased by $\sim 25 \%$ from those at admission, were associated with the restrictive type of anorexia nervosa, the presence of infectious complications, and a long duration of illness. Second, the presence of infectious complications was also associated with a greater rate of decrease in all three hematological 
values. Third, volume depletion at admission, expressed by a high BUN/Cr ratio at admission, was associated with a greater rate of decrease in the platelet count.

The $\sim 25 \%$ decrease observed in all three hematological cell measures and their nadir values during the refeeding period are similar to findings of the previous study by Sable et al, in which the average hemoglobin was decreased by $16.0 \%$ to $10.5 \mathrm{~g} / \mathrm{dl}$, white blood cell count by $20.0 \%$ to $3200 / \mu \mathrm{l}$, and platelets by $20.1 \%$ to $21.4 \times 10^{4} / \mu \mathrm{l}$ [2]. In their study, 53 anorexic patients with an average body mass index of 12.9 were recruited [2], which is similar to the average body mass index (13.4) of our cohort. We observed pancytopenia in $17.9 \%$ of patients, which is again consistent with their findings that $23 \%$ of patients experienced pancytopenia [2], suggesting that deficiencies of all three hematological cell measures are occasionally found in these cohorts. Likewise, significant correlations among the three hematological cell values were also revealed in our present study. These findings suggest that the bone marrow does not function well overall, which is consistent with the presence of bone marrow hypoplasia in patients with anorexia nervosa $[1,2]$.

The average mean corpuscular volume of $91.3 \mathrm{fl}$ in our cohort was also quite similar to that of the cohort analyzed by Sable et al, in which the mean corpuscular volume was $91.7 \mathrm{fl}$ [2]. According to Sable et al [2], anemia almost never arose among their cohort due to iron deficiency, chronic disease, or vitamin B12 and/or folate deficiency despite extreme dietary restriction and the individuals being underweight for an extended period of time. Furthermore, they postulated that because the vast majority of women with anorexia nervosa have amenorrhea from reversion of their hypothalamic-pituitary-ovarian axis to a prepubertal state, they do not lose blood and iron with monthly menses [2]. In their cohort, $13 \%$ of the patients had macrocytic anemia, yet none had vitamin B12 or folate deficiency. We also found that $15.8 \%$ of our cohort had macrocytic anemia at admission and none of the participants had vitamin B12 or folate deficiency, although these laboratory data were not available for all admissions with macrocytic anemia. Rather, the ratio of reticulocytes (i.e., young red blood cells with an $\sim 27 \%$ larger volume when compared with mature red blood cell [35]) was high when these patients were anemic although these laboratory data again were not available for all admissions with macrocytic anemia. This might suggest that their high mean corpuscular volume levels reflected a larger proportion of reticulocytes, but not macrocytic anemia due to vitamin B12 and/or folate deficiency, and that blood formation in bone marrow was accelerated after they were refed, which subsequently led to a V-shaped recovery of hematological values.

The association between malnutrition (body mass index, the restrictive type of anorexia nervosa, and duration of illness) and hematological deficiencies in our study is consistent with previous reports $[2,3,5$, $8,9]$, although these previous studies did not control for potential cofounding factors. What was not previously known is that this relationship further applies to the hematological values during the refeeding period, in which the lowest hematological cell measures are observed. The restrictive type of anorexia nervosa was found to be a decisive factor that is associated with the nadir hemoglobin level and white blood cell count, and a longer duration of illness was associated with a lower nadir white blood cell count. The fact that the restrictive type was associated with lower hemoglobin and white blood cell nadir 
values suggests that there might be a distinctive malnutrition pattern in the restrictive type of anorexia nervosa, in which malnutrition is continuous and may be severe when compared with the binge-purge type, even when the body mass index is similar among patients. Indeed, our previous study revealed that the restrictive type independently is associated with the development of refeeding hypophosphatemia, a hallmark of refeeding syndrome, among anorexic patients with severe malnutrition, and this association was independent of a low body mass index [20]. Similarly, we also previously found that the extent of the decrease in potassium during the refeeding period is greater for the restrictive type than for the bingepurge type of anorexia nervosa [29]. Given these findings, it is reasonable to consider that the restrictive type itself poses a risk of organ dysfunction and electrolyte depletion. A long duration of illness, another independent factor associated with hematological deficiencies, has been considered to alter the bone marrow microenvironment, which might lead to defective hematopoiesis and its consequent hematological deficiencies [8].

Infectious complications are closely associated with a lower hemoglobin and platelet nadir levels as well as a greater rate of decrease in all hematological cell measures. A close relationship between a greater rate of decrease in white blood cell count and infectious complications is considered to be attributable to a great extent of decrease in the white blood cell count from an elevated level at the peak of an infection to a lower level after recovery. The relationship between infectious diseases and anemia has been proposed in the context of hematopoietic cell regulation [14]. According to Gomes et al [14], during infection, systemic signals such as inflammatory cytokines can prompt hematopoietic stem progenitor cell (cells responsible for hematopoiesis through self-renewal and differentiation into mature blood cell lineages) to be directed to specific hematopoietic lineages (e.g., myeloid) at the expense of others (e.g., erythroid). Thus, in bone marrow, chronic exposure to inflammatory systemic signals triggers a blockade of erythropoiesis, the process producing red blood cells, and subsequently leads to the development of anemia [14]. For patients with anorexia nervosa whose bone marrow is already hypoplastic, the presence of infectious diseases and its subsequent blockade of erythropoiesis might have a devastating impact on the production of red blood cells. The platelet count decline is considered to be resulted from two factors, i.e., the development of disseminated intravascular coagulation [17], in which platelets play an important role in the development of micro thrombosis [36], and the decrease in the platelet count from an elevated level at the peak of an infection to a lower level after recovery [18]. A low nadir platelet level was considered to be resulted from the development of disseminated intravascular coagulation following an infectious disease.

Although volume depletion has been postulated to raise hemoglobin and platelet levels [11-13], there has been no study to investigate this influence on actual these levels of anorexic patients. Our present study found that a higher BUN/Cr ratio was associated with a greater rate of decrease in the platelet count. These findings suggest that volume depletion might seemingly raise the hematological values at admission via hemoconcentration and lead to a substantial decrease in those levels during the refeeding period as patients are refed and volume depletion is resolved. However, there was no association between $\mathrm{BUN} / \mathrm{Cr}$ ratio and the rate of decrease in the hemoglobin level in our current study. Thus, these issues should be addressed in future studies with a large-scale cohort. 


\section{Limitations}

Our study has several limitations that should be considered. First, although we tried to investigate the three blood cell measures frequently in each patient, ideally these levels should be examined every day during the refeeding period to precisely determine the nadir levels. Second, we were unable to investigate the level of neutrophils, the most numerous type of white blood cells that lead the immune system's response, because hematological data of some patients did not include those of neutrophile. In a previous study [2], however, the extent of the decrease in white blood cell count $(800 / \mu l)$ was exactly the same as that of neutrophil count $(800 / \mu \mathrm{l})$ during the refeeding period of anorexic patients, suggesting that the change in the white blood cell count might be quite similar to the change in the neutrophil count in anorexic patients during the refeeding period. Third, this study included data collected over a period of nearly 20 years. Some treatment strategies might have changed, in particular, the adoption of a highercalorie diet during the refeeding period [37-41]. However, the amount of calorie intake was controlled for in our general mixed model. Fourth, the study population was not large. Finally, the generalizability of our results is limited because our study population was derived from a single hospital. These issues should be addressed in future studies.

\section{Conclusions}

Our study found that the anorexia nervosa restrictive type, the presence of infectious complications, and a long duration of illness were associated with hematological deficiencies in patients with anorexia nervosa during the refeeding period, during which further decreases in hematological values were observed.

\section{Abbreviations}

AST, aspartate oxoglutarate aminotransferase; $\mathrm{BUN} / \mathrm{Cr}$ ratio, blood urea nitrogen/creatinine ratio

\section{Declarations}

\section{Ethics committee approval}

Ethical aspects of this study were reviewed and approved by the Ashikaga Red Cross Hospital Human Research Ethics Committee (2012-16).

\section{Consent to participate}

This study was performed after obtaining informed consent from all participants upon admission. For the patients who were $<18$ years of age, informed consent was also obtained from that individual's parents.

\section{Consent for publication}


Not applicable.

\section{Availability of data and materials}

The datasets generated and/or analyzed during the current study are available from the corresponding author (MF) upon request.

\section{Competing interests}

The authors declare that they have no competing interests.

\section{Funding}

The authors report that there were no sources of funding.

\section{Authors' contributions}

MF, AK, YM, TT, SO, S. Kurose, YS, and S. Kudo acquired case data. MF, AK, and YM drafted the manuscript. All authors read and approved the final manuscript.

\section{Acknowledgements}

We wish to thank the patients who participated in these studies.

\section{References}

1. Hütter G, Ganepola S, Hofmann WK. The hematology of anorexia nervosa. Int J Eat Disord. 2009;42:293-300. https://doi.org/10.1002/eat.20610

2. Sable AL, Gaudiani JL, Statland B, Mehler PS. Hematological abnormalities in severe anorexia nervosa. Ann Hematol. 2013;92:605-613. https://doi.org/10.1007/s00277-013-1672-x

3. Gibson D, Watters A, Cost J, Mascolo M, Mehler PS. Extreme anorexia nervosa: medical findings, outcomes, and inferences from a retrospective cohort. J Eat Disord. 2020; 8: 25. https://doi.org/10.1186/s40337-020-00303-6

4. Guinhut M, Melchior JC, Godart N, Hanachi M. Extremely severe anorexia nervosa: Hospital course of 354 adult patients in a clinical nutrition-eating disorders-unit. Clinical Nutrition. 2021; 40: 1954-1964. https://doi.org/10.1016/j.clnu.2020.09.011

5. Guinhut M, Godart N, Benadjaoud MA, Melchior JC, Hanachi M. Five-year mortality of severely malnourished patients with chronic anorexia nervosa admitted to a medical unit. Acta Psychiatr Scand. 2021; 143: 130-140. https://doi.org/10.1111/acps.13261

6. Harbottle EJ, Birmingham CL, Sayani F. Anorexia nervosa: a survival analysis. Eat Weight Disord, 2008; 13: e32-4. 
7. Cleary BS, Gaudiani JL, Mehler PS. Interpreting the complete blood count in Anorexia Nervosa. Eating Disorders, 2010; 18: 132-139. https://doi.org/ 10.1080/10640260903585540

8. De Filippo E, Marra M, Alfinito F, Di Guglielmo M, Majorano P, Cerciello G, De Caprio C, Contaldo F, Pasanisi F. Hematological complications in anorexia nervosa. European Journal of Clinical Nutrition. 2016; 70: 1305-1308. https://doi.org/10.1038/ejcn.2016.115

9. Walsh K, Blalock DV, Mehler PS. Hematologic findings in a large sample of patients with anorexia nervosa and bulimia nervosa. American Journal of Hematology. 2020; 95: E98-E101. https://doi.org/10.1002/ajh.25732

10. Takeshima M, Ishikawa H, Kitadate A, Sasaki R, Kobayashi T, Nanjyo H, Kanbayashi T, Shimizu T. Anorexia nervosa-associated pancytopenia mimicking idiopathic aplastic anemia: a case report. BMC Psychiatry. 2018; 18: 150. https://doi.org/10.1186/s12888-018-1743-6

11. Akimoto T, Ito $C$, Kato M, Ogura M, Muto S, Kusano E. Reduced hydration status characterized by disproportionate elevation of blood urea nitrogen to serum creatinine among the patients with cerebral infarction. Med Hypotheses. 2011; 77: 601-4. https://doi.org/10.1016/j.mehy.2011.06.044

12. Sahin S, Durgut BD, Dilber B, Arslan EA, Kamasak T, Cansu A. Increased hemoglobin and plateletcrit levels indicating hemoconcentration in pediatric patients with migraine. J Pediatr Neurosci. 2020; 15: 99-104. https://doi.org/10.4103/jpn.JPN_73_19

13. Andrews NP, Gralnick HR, Merryman P, Vail M, Quyyumi AA. Mechanisms underlying the morning increase in platelet aggregation: A flow cytometry study. J Am Coll Cardiol 1996; 28: 1789 -1795.

14. Gomes AC, Gomes MS. Hematopoietic niches, erythropoiesis and anemia of chronic infection. Experimental Hematology 2016; 44: 85-91. http://dx.doi.org/10.1016/j.exphem.2015.11.007

15. Oh TK, Song KH, Song IA. History of anemia and long-term mortality due to infection: a cohort study with 12 years follow-up in South Korea.

16. Honda T, Uehara T, Matsumoto G, Arai S, Sugano M. Neutrophil left shift and white blood cell count as markers of bacterial infection. Clinica Chimica Acta 2016; 457: 46-53.

http://dx.doi.org/10.1016/j.cca.2016.03.017

17. Koyama K, Madoiwa S, Tanaka S, Koinuma T, Wada M, Sakata A, Ohmori T, Mimuro J, Nunomiya S, Sakata Y. Evaluation of hemostatic biomarker abnormalities that precede platelet count decline in critically ill patients with sepsis. Journal of Critical Care 2013; 28: 556-563. http://dx.doi.org/10.1016/j.jcrc.2012.10.069

18. Gofrit ON, Shapiro A, Rund D, Verstandig AG, Landau EH, Katz R, Shenfeld OZ, Gdor Y, Pode D. Thrombocytosis accompanying urinary tract infection suggests obstruction or abscess. Am J Emerg Med 2006; 24: 118-21. doi: 10.1016/j.ajem.2005.05.007

19. Belok SH, Bosch NA, Klings ES, Walkey AJ. Evaluation of leukopenia during sepsis as a marker of sepsis-defining organ dysfunction. PLoS One 2021; 24: 16(6): e0252206. doi: 10.1371/journal.pone.0252206

20. Funayama M, Mimura Y, Takata T, Koreki A, Ogino S, Kurose S. Body mass index and blood urea nitrogen to creatinine ratio predicts refeeding hypophosphatemia of anorexia nervosa patients with 
severe malnutrition. J Eat Disord. 2021; 9: 1. https://doi.org/10.1186/s40337-020-00356-7

21. Portolés J, Martín L, Broseta JJ, Cases A. Anemia in chronic kidney disease: From pathophysiology and current treatments, to future agents. Front Med (Lausanne). 2021; 8: 642296. https://doi.org/10.3389/fmed.2021.642296. eCollection 2021.

22. Alkozai EM, Nijsten MW, de Jong K, de Boer MT, Peeters PMJG, Slooff MJ, Porte RJ, Lisman T. Immediate postoperative low platelet count is associated with delayed liver function recovery after partial liver resection. Ann Surg. 2010; 251: 300-6. https://doi.org/10.1097/SLA.0b013e3181b76557

23. Au KP, Chan SC, Chok KSH, Chan ACY, Cheung TT, Ng KKC, Lo CM. Child-Pugh parameters and platelet count as an alternative to ICG test for assessing liver function for major hepatectomy. HPB Surgery. 2017; 2948030: 8. https://doi.org/10.1155/2017/2948030

24. Hanachi M, Melchior JC, Crenn P. Hypertransaminasemia in severely malnourished adult anorexia nervosa patients: risk factors and evolution under enteral nutrition. Clin Nutr 2013 32: 391-5. https://doi.org/10.1016/j.clnu.2012.08.020

25. Rosen E, Sabel AL, Brinton JT, Catanach B, Gaudiani JL, Mehler PS. Liver dysfunction in patients with severe anorexia nervosa. Int J Eat Disord. 2016 Feb;49(2):151-8. doi: 10.1002/eat.22436

26. Imaeda M, Tanaka S, Fujishiro H, Kato S, Ishigami M, Kawano N, Katayama H, Kohmura K, Ando M, Nishioka K, Ozaki N. Risk factors for elevated liver enzymes during refeeding of severely malnourished patients with eating disorders: a retrospective cohort study. J Eat Disord. 2016 Dec 7; 4: 37. doi: 10.1186/s40337-016-0127-x

27. Zhao JV, Kwok MK, Schooling CM. Effect of glutamate and aspartate on ischemic heart disease, blood pressure, and diabetes: a Mendelian randomization study. Am J Clin Nutr 2019; 109: 11971206. https://doi.org/10.1093/ajcn/nqy362

28. Kameoka N, Iga J, Tamura M, Tominaga T, Kubo H, Watanabe Y, Sumitani S, Tomotake M, Omori T. Risk factors for refeeding hypophosphatemia in Japanese inpatients with anorexia nervosa. Int $\mathrm{J}$ Eat Disord. 2016; 49: 402-6. https://doi.org/10.1002/eat.22472

29. Funayama M, Mimura Y, Takata T, Koreki A, Ogino S, Kurose S, Shimizu Y. Hypokalemia in patients with anorexia nervosa during refeeding is associated with binge-purge behavior, lower body mass index, and hypoalbuminemia. J Eating Disorder. 2021; 9: 95. https://doi.org/10.1186/s40337-02100452-2

30. Morino K, Kondo K, Tanaka S, Nishida Y, Nakae S, Yamada Y, Ugi S, Fuse K, Miyazawa I, Ohi A, Nishida K, Kurihara M, Sasaki M, Ebine N, Sasaki S, Katsukawa F, Hiroshi M. Total energy expenditure is comparable between patients with and without diabetes mellitus: Clinical Evaluation of Energy Requirements in Patients with Diabetes Mellitus (CLEVER-DM) Study. BMJ Open Diabetes Res Care 2019; 7, e000648. https://doi.org/10.1136/bmjdrc-2019-000648 eCollection 2019

31. Harrington $\mathrm{BC}$, Jimerson M. Initial evaluation, diagnosis, and treatment of anorexia nervosa and bulimia nervosa. Am Fam Physician. 2015;91: 46-52

32. https://www.mhlw.go.jp/topics/2006/11/dl/tp1122-1f03.pdf 
33. Parasuraman S, Yu J, Paranagama D, Shrestha S, Wang L, Baser O, Scherbet R. Hematocrit levels and thrombotic events in patients with polycythemia vera: an analysis of Veterans Health Administration data. Annals of Hematology 2019; 98: 2533-2539. https://doi.org/10.1007/s00277019-03793-w

34. https://www.jsth.org/wordpress/wp-content/uploads/2015/04/DIC_3.pdf

35. Arora RD, Dass J, Maydeo S, Arya V, Kotwal J, Bhargava M. Utility of mean sphered cell volume and mean reticulocyte volume for the diagnosis of hereditary spherocytosis. Hematology. 2018; 23: 413416. https://doi.org/10.1080/10245332.2018.1423879

36. Laursen MA, Larsen JB, Hyas AM. Platelet function in disseminated intravascular coagulation: A systematic review. Platelets 2018. 29: 238-248. https://doi.org/10.1080/09537104.2018.1442567

37. Whitelaw M, Gilbertson H, Lam PY, Sawyer SM. Does aggressive refeeding in hospitalized adolescents with anorexia nervosa result in increased hypophosphatemia? J Adolesc Health. 2010; 46: 577-82. https://doi.org/10.1016/j.jadohealth.2009.11.207

38. Garber AK, Michihata N, Hetnal K, Shafer MA, Moscicke AB. A prospective examination of weight gain in hospitalized adolescents with anorexia nervosa on a recommended refeeding protocol. $J$ Adolesc Health. 2012; 50: 24-9. https://doi.org/10.1016/j.jadohealth.2011.06.011

39. O'Connor G, Nicholls D. Refeeding hypophosphatemia in adolescents with anorexia nervosa: a systematic review. Nutr Clin Pract. 2013; 28: 358-64. https://doi.org/10.1177/0884533613476892

40. Garber AK, Mauldin K, Michihata N, Buckelew SM, Shafer MA, Moscicki AB. Higher calorie diets increase rate of weight gain and shorten hospital stay in hospitalized adolescents with anorexia nervosa. J Adolesc Health. 2013; 53: 579-84. https://doi.org/10.1016/j.jadohealth.2013.07.014

41. Katzman DK, Garber AK, Kohn M, Golden NH. Refeeding hypophosphatemia in hospitalized adolescents with anorexia nervosa. J Adolesc Health. 2014; 55: 455-7. https://doi.org/10.1016/j.jadohealth.2014.06.010

\section{Supplementary Files}

This is a list of supplementary files associated with this preprint. Click to download.

- 2021.11.14Fm711122NNsubmitJEatDisHematological.pdf 